\title{
DINAMIKA PENDIDIKAN ISLAM DAN LIBERALISASI PENDIDIKAN DI INDONESIA
}

\author{
Abdul hadi \\ Email: habdulhadi.uij@gmail.com \\ Universitas Islam Jember
}

\begin{abstract}
Abstrak
Tulisan ini tentang dinamika pendidikan Islam dan liberalisasi pendidikan hal ini berangkat dari regulasi pendidikan Islam yang masuk pada pusaran libelisme barat. Liberalisasi pendidikan merupakan formula baru untuk merumuskan konsep pendidikan secara ideal sehingga dalam proses belajar-mengajar seorang guru harus memahami perkembangan anak-anak didiknya secara kritis dan berkelanjutan. Pendidikan Islam dan liberalisasi pendidikan adalah suatu usaha untuk merubah atau mereformasi tatanan pendidikan sehingga dunia pendidikan lebih maju dan memberikan warna segar agar pendidikan Islam berjalan secara dinamis. Liberalisasi pendidikan bukan berarti sebebas-bebasnya tetapi harus sejalan dengan nilai-nilai pendidikan Islam yang harus disesuaikan dengan perkembangan zaman sehingga tidak tertinggal untuk mengikuti perkembangan dunia pendidikan. Sementara dalam pendidikan Islam konsep hakiki yang sesuai dengan nilai dalam konsep Islam berorientasi tidak hanya untuk dunia semata melainkan juga sekaligus untuk meraih kesuksesan, kebahagiaan, dan kemaslahatan di alam akhirat.
\end{abstract}

Kata Kunci: Pendidikan Islam, liberalisasi pendidikan, Relevansinya.

\begin{abstract}
This paper on the dynamics of Islamic education and the liberalization of education departs from the regulation of Islamic education that entered the vortex of western libelism. Liberalization of education is a new formula to formulate the concept of education ideally so that in the process of teaching and learning a teacher must understand the development of his students critically and sustainably. Islamic education and education liberalization is an attempt to change or reform the order of education so that the world of education is more advanced and provides fresh colors so that Islamic education runs dynamically. Liberalization of education does not mean free but must be in line with islamic educational values that must be adapted to the times so as not to be left behind to keep up with the development of the world of education. While in Islamic education the concept of essence in accordance with the values in the Islamic concept is oriented not only to the world but also at the same time to achieve success, happiness, and benefit in the afterlife.
\end{abstract}

Keywords: Islamic Education, liberalization of education, Relevance.

\section{PENDAHULUAN}

Pendidikan atau dalam bahasa Arab tarbiyah dari sudut pandang etimologi (ilmu akar kata) berasal dari tiga kelompok kata, pertama, raba, yarbu yang berarti bertambah dan bertumbuh. Kedua, rabiya, yarba yang berarti menjadi besar. Dan ketiga, rabba yarubbu yang berarti memperbaiki, menguasai urusan, menuntut, menjaga, dan memelihara. Pendidikan harus dipahami sebagai suatu proses. Proses yang sedang 


\section{Abdul Hadi}

mengalami pembaruan/perubahan ke arah yang lebih baik. ${ }^{1}$ Keberadaan pendidikan Islam sebagai salah satu agen perubahan sosial yang dituntut untuk mempu mengimbangi gerakan modernisasi dan globalisasi yang merabah pada berbagai aspek kehidupan. Keberadannya diharapkan dapat bergerak secara dinamis dan proaktif terhadap perkembangan zaman.

Selain itu, kehadirannya diharapkan dapat membawa perubahan yang bagus dan kontribusi yang nyata bagi masyarakat kususnya pada pengembangan pendidikan Islam di Indonesia. Ilmu pendidikan atau pedagogik adalah ilmu yang membicarakan masalah-masalah umum pendidikan, secara menyeluruh dan abstrak. Pedagogik, selain bercorak teoritis, juga bersifat praktis. Untuk yang teoritis diutarakan hal-hal yang bersifat normatif ialah hal-hal yang menunjuk kepada standar nilai tertentu; sedangkan yang praktis menunjukkan bagaimana pendidikan itu harus dilaksanakan. Teori dan praktik ibarat dua sisi mata uang yang saling berhubungan dan tidak bisa berdiri sendiri. Teori, pada hakekatnya terdiri atas konsep-konsep yang tersusun logis. Konsep adalah pengertian-pengertian yang sifatnya abstrak yang melandasi praktik, dan teori seyogyanya bermuara dalam praktik. ${ }^{2}$

Pendidikan Islam seringkali berhadapan dengan berbagai problematika yang tidak ringan. Sebagai sebuah sistem, pendidikan Islam mengandung berbagai komponen antara satu dan lainnya saling berkaitan. Komponen pendidikan tersebut meliputi landasan, tujuan, kurikulum, kompetensi dan profesionalisme guru, pola hubungan murid, metodologi pembelajaran, sarana prasarana, evaluasi pembiayaan dan lain sebagainya. Berbagai komponen yang terdapat dalam pendidikan ini seringkali berjalan apa adanya, alami dan tradisional, tanpa konsep manajerial yang lengkap dan jelas. Akibat dari keadaan demikian, maka mutu pendidikan Islam seringkali menunjukkan keadaan yang kurang menggembirakan.

Pendidikan merupakan bagian dari kebutuhan hidup yang harus dipenuhi setiap orang dan merupakan tema yang sangat menarik untuk dikaji, sehingga menciptakan karya dalam dunia pendidikan. Pendidikan juga merupakan hal yang sangat penting bagi pembangunan bangsa. Tidak hanya pembangunan secara fisik, tetapi juga pembangunan secara psikis atau mental. Sebuah bangsa akan berkembang

\footnotetext{
${ }^{1}$ Jasa Ungguh Muliawan, Pendidikan Islam Integratif: Upaya Mengintegrasikan Kembali Dikotomi Ilmu dan Pendidikan Islam, (Yogyakarta: Pustaka Pelajar, 2005), 9

2 Jasa Ungguh Muliawan, Pendidikan Islam Integratif: Upaya Mengintegrasikan Kembali Dikotomi Ilmu dan Pendidikan Islam..78
} 
dan dapat bersaing dengan bangsa-bangsa lain di dunia, jika pendidikannya baik dan bermutu, karena pendidikan bersifat multidimensional dan memiliki tautan dengan berbagai aspek dalam kehidupan manusia.

Pendidikan juga memiliki posisi yang sangat strategis untuk memperbaiki kondisi bangsa. Disadari atau tidak, diakui atau tidak, bahwa masih banyak potret kelam wajah pendidikan nasional. Kalau telusuri lebih jauh, maka termasuk pada satu dunia yang penuh carut-marut, dan sulit untuk diuraikan persoalan apa sesungguhnya yang menjadi masalah dalam tubuh pendidikan. Sebagai sebuah bangsa yang wajib menjunjung tinggi harkat dan martabat bangsa, tidak boleh melihat persoalanpersoalan tersebut dari kaca mata yang selalu pesimis. Karena jika demikian, maka tidak akan pernah memiliki sebuah harapan untuk keluar dari keterpurukan.

Kritikan dan masukan yang konstruktif adalah sebuah tindakan yang lebih bijak, daripada hanya merenungi dan meratapi nasib pendidikan yang tak kunjung membaik. Diperlukan perhatian yang serius dari semua pihak untuk bersama-sama mengevaluasi pendidikan nasional. Pendidikan pada dasarnya berkaitan dengan masalah ilmu. Apalagi pendidikan agama, yang berkaitan dengan ilmu-ilmu agama (ulumuddin). Sudah bukan rahasia lagi, kekacauan konsep ilmu telah menyebabkan munculnya dampak yang sangat serius di kalangan kaum Muslim saat ini. ${ }^{3}$ Melalui pendidikan akan merubah manusia menjadi baik dan beradab. Pendidikan juga membentuk karakter seseorang menjadi lebih baik melalui proses pembelajaran, karena orang akan belajar dari hal yang tidak dimengerti menjadi mengerti. Inilah yang menjadi tolak ukur pengetahuan yang dimiliki seseorang. Penjelasan di atas memberikan arahan dalam pemaparan makalah ini tentang liberalisasi pendidikan yang ditinjau dari pendidikan Islam serta pengaruh perkembangan liberalisasi. Sistem pendidikan yang berhaluan liberal kapitalistik adalah seluruh bentuk pengelolaan pendidikan yang dijadikan sebagai sarana untuk memperoleh keuntungan finansial belaka, yang tidak menghiraukan lagi pentingnya pendidikan bagi setiap anak. Sehingga sekolah-sekolah yang menolak seorang calon peserta didik karena tidak mampu membayar uang sekolah, maka sekolah-sekolah tersebut digolongkan sebagai sekolah kapitalis. ${ }^{4}$

\footnotetext{
${ }^{3}$ Adian Husaini, Islam Liberal, Pluralisme Agama dan Diabolisme Intelektual, (Surabaya: Risalah Gusti, 2005), 85

${ }^{4}$ Marjuni, Kapitalisme Dan Pendidikan Liberal, Jurnal wawasan Keislaman, Vol.6 No.2, 2011.
} 


\section{Abdul Hadi}

\section{METODE}

Pendekatan penelitian yang digunakan untuk dapat mencapai tujuan tersebut adalah pendekatan kualitatif dengan menggunakan metode kajian pustaka (studi pustaka), yaitu menelusuri literatur yang ada serta menelaahnya secara tekundan kristis. Dengan demikian, peneliti berusaha mengungkap berbagai data yang terdapat dalam berbagai literatur untuk dijadikan rujukan dalam tulisan ini. Sedangkan tahapan analisis data yang digunakan adalah tahapan reduksi data, penyajian data dan penarikan kesimpulan.

\section{PEMBAHASAN}

\section{Kajian Pendidikan Islam}

Tujuan pendidikan, sebagai salah satu komponen pendidikan merupakan landaan pertama dalam proses pendidika. Formula pembelajaran Pendidikan Islam saat ini dirasakan sangat tidak menjamin peserta didik maupun pendidik menjadi lebih baik dalam penerapannya, karena pada umumnya dikalangan ahli pendidikan sangat sulit untuk menentukan kriteria Pendidikan Islam yang baik dan benar. Kenyataannya dapat dilihat di dunia pendidikan, sering terjadinya kekerasan dan tawuran antara murid maupun guru. Pembenahan dasar pendidikan Islam secara idealnya belum begitu terealisasi dan menjiwai di dunia pendidikan.

Dasar pendidikan Islam adalah al-Qur'an dan Hadits dan kalau pendidikan itu diibaratkan bangunan maka isi al-Qur'an dan al-Hadits itu menjadi fondamennya. AlQur'an mencakup segala masalah baik yang mengenai peribadatan maupun kemasyarakatan maupun pendidikan. Pendidikan ini mendapat tuntunan yang jelas dalam al-Qur'an dan al-Hadits. Sebagaimana dalam Hadits ada yang mengatakan bahwa menuntut ilmu itu wajib bagi setiap muslim dan muslimat dari buaian hingga liang lahat. Kedua unsur tersebut banyak nilai-nilai yang dapat dijadikan dasar bagi pendidikan Islam. Di sini diutarakan nilai yang dipandang fundamental dan dapat merangkum berbagai nilai yang lain yaitu tauhid, kemanusian, kesatuan umat Islam, keseimbangan dan rohmatan lil alamin. ${ }^{5}$

Pendidikan agama Islam harus didekatkan dengan realitas masyarakatnya bukan berada pada persimpangan yang membingungkan (menguatkan doktrin melemahkan solidaritas sosial). Pendidikan agama harus mampu menyapa masyarakat yang papah dan hina sehingga menumbuhkan sikap dan cara pandang yang manusiawi atas umat

${ }^{5}$ Mansur Isna, Diskursus Pendidikan Islam, (Yogyakarta: Global Pustaka Utama, 2001), 63 
manusia tanpa adanya perasaan bahwa mereka adalah bukan dari bagian kita akibat kuatnya formalisasi agama dalam pendidikan agama selama ini. Tentu saja pendidikan yang demikian harus dirombak total sekarang juga. ${ }^{6}$ Proses pendidikan yang menjunjung tinggi pluralisme merupakan pendidikan yang sejatinya sangat cocok untuk kehidupan bersama di negeri ini yang sejak awal menempatkan agama sebagai basis moral-etika, bukan sebagai dasar negara seperti dibeberapa negara yang menjadikan agama sebagai dasar resmi negara. ${ }^{7}$

Penjelasan di atas dapat disimpulkan bahwa pendidikan agama Islam haruslah sejalan dengan perkembangan kebutuhan hidup yang selalu mengalami perubahanperubahan yang disebabkan oleh globalisasi dan perkembangan iptek. Kualitas atau mutu pendidikan harus diupayakan untuk mencapai kemajuan yang dilandasi oleh suatu perubahan terencana menurut segala peningkatan mutu pendidikan diperoleh melalui dua strategi, yaitu: 1) peningkatan mutu pendidikan yang berorientasi akademis untuk memberi dasar minimal dalam perjalanan yang harus ditempuh untuk mencapai mutu pendidikan yang dipersyaratkan oleh tuntutan zaman, 2) peningkatan mutu pendidikan yang berorientasi padaketerampilan hidup, esensial, yang dicakupi oleh pendidikan yang berlandasan luas, nyata, dan bermakna. $^{8}$

\section{Liberalisasi Pendidikan sebuah Kajian Kritis}

Liberalisme merupakan pandangan ideologi yang sangat berpengaruh dalam pemikiran dan intuisi barat, menekankan kepada individualisme dan kepemilikan pribadi, yang kemudian diinjeksikan ke dalam sistem sekolah (pendidikan) di Amerika.

Dalam disertasi di Monash University Australia, Greg Barton menjelaskan beberapa prinsip gagasan Islam liberal yang dikembangkan di Indonesia: (a) Pentingnya kontekstualisasi ijtihad, (b) Komitmen terhadap rasionalitas dan pembaharuan, (c) Penerimaan terhadap pluralisme sosial dan pluralisme agamaagama, (d) Pemisahan agama dari partai politik dan adanya posisi non-sektarian

${ }^{6}$ Zuly Qodir, Belajar Dari Kisah Kearifan Sahabat: Ikhtiar Pengembangan Pendidikan Islam, (Yogyakarta: Pilar Media, 2007), 9

${ }^{7}$ Zuly Qodir, Belajar Dari Kisah Kearifan Sababat..... 12

8 Asnawan, A. (2020). Relevansi Kebijakan dalam Peningkatan Mutu Pendidikan Agama Islam. Tafbim Al'Ilmi, 11(2), 223-240. https://doi.org/10.37459/tafhim.v11i2.3751

9 Gerald L Gutek, Philosophical and Ideological Perspectives on Education, (New Jersey: Englewood Cliffs, 1988), 189 


\section{Abdul Hadi}

negara. Menurut Barton ada empat tokoh Islam Liberal di Indonesia, yaitu; Abdurrahman Wahid, Nurcholish Madjid, Ahmad Wahib dan Djohan Effendi. ${ }^{10}$

Pius A. Partanto dan M. Dahlan Al Barry mendefinisikan liberalisme sebagai paham yang menekankan kebebasan individu atau partikelir, filsafat sosial politik, dan ekonomi yang menekankan atau mengutamakan kebebasan individu untuk mengadakan perjanjian, produksi, konsumsi, tukar-menukar, dan bersaing serta hak milik partikelir (swasta) terhadap semua macam barang. ${ }^{11}$

Syaikh Sulaiman al-Khirasy menyebutkan, liberalisme adalah madzhab pemikiran yang memperhatikan kebebasan individu. Madzhab ini memandang, wajibnya menghormati kemerdekaan individu, serta berkeyakinan bahwa tugas pokok pemerintah adalah menjaga dan melindungi kebebasan rakyat, seperti kebebasan berfikir, kebebasan menyampaikan pendapat, kebebasan kepemilikan pribadi, kebebasan individu, dan sejenisnya. ${ }^{12}$

Jika diteliti dari berbagai tulisan yang disebarkan kaum Islam Liberal di Indonesia, boleh disimpulkan ada beberapa pokok-pokok ajaran Islam Liberal ini, yaitu: (1) menghancurkan akidah Islam dengan menyebarkan paham Pluralisme agama, (2) meruntuhkan bangunan syariat Islam dengan program "kontekstualisasi ijtihad" dan penggunaan metodologi interpretasi hermeutika terhadap al-Qur'an, (3) membongkar konsep al-Qur'an sebagai wahyu Allah, lafdhan wa ma'nan minallah, yang suci dari kesalahan, (4) membongkar konsep-konsep dasar Islam seperti makna iman, kufur, murtad, islam dan sebagainya, (5) meruntuhkan otoritas ulama dalam pemahaman Islam dan (6) mendukung kerusakan akhlak dengan berpegang pada paham liberalisme dan relativisme moral. ${ }^{13}$

\section{Liberalisme Pendidikan}

Pendidikan liberal dibangun dari berbagai pandangan dan paradigma, baik pandangan ideologis politis maupun saintis paradigmatik metodologis. Selain faktor politis, banyaknya pandangan dan sumber etika yang mempengaruhi itulah barangkali

\footnotetext{
10 Amin Nasrulah, Pendidikan Liberal, Reproduksi Kapitalisme, dan Kemandengan Transformasi Sosial, oleh Greg Barton, Gagasan Islam Liberal di Indonesia: Pemikiran Neomodernisme Nurcholish Madjid, Djohan Effendi, Ahmad Wabib, dan Abdurrabman Wabid, (Jakarta: Paramadina, 1999), 82

11 A. Partanto, Pius. dan Al-Barry, M. Dahlan. Kamus Ilmiah Populer. Surabaya: Arkola,1994.

12 Soleh Subagja. Gagasan Liberalisme Pendidikan Islam. (Malang : Madani. 2010), 49

13 Adian Husaini,...hlm x-xi
} 
yang dapat menjelaskan mengapa dalam liberalisme terdapat ambivalensi, ambiguitas, dan watak yang saling kontradiktif. ${ }^{14}$

Paradigma liberal, baik dalam pengertian politik ideologis maupun dalam pendidikan, dalam sisi-sisi tertentu mempunyai watak sebagaimana dimiliki paradigma konservatif, yakni ciri-ciri anti perubahan, mendukung kemapanan (status quo), serta reproduksi sosial. Paham liberal memang tidak secara langsung menentang perubahan, namun beberapa teori dan pendekatan yang mereka pakai dalam analisis sosial, misalnya structural fungsionalism, meyebabkan paham ini lebih dekat dan lebih menyukai status quo. Paradigma liberal, meskipun setuju dengan perubahan, tetapi perubahan yang terjadi dengan sendirinya, tanpa diusahakan dan tanpa pengarahan (laissez faire), netral dan lamban tanpa ada kepastian karena akan berjalan sesuai dengan terjadinya evolusi. ${ }^{15}$

Dalam setiap unsurnya, pendidikan liberal tentu saja dipengaruhi oleh etik liberal secara keseluruhan, dengan demikian apa yang berpengaruh dan membentuk pandangan liberalisme juga ikut berpengaruh dan membentuk paradigma pendidikan liberal. Ada beberapa asumsi yang mendukung konsep manusia "rasional liberal" seperti: pertama bahwa semua manusia memiliki potensi sama dalam intelektual, kedua baik tatanan alam maupun norma sosial dapat ditangkap oleh akal. Ketiga adalah "individualis" yakni adanya angapan bahwa manusia adalah atomistik dan atanom. Menetapkan individu secara atomistic, membawa pada keyakinan bahwa hubungan sosial sebagai kebetulan, dan masyarakat dianggap tidak stabil karena interest anggotanya yang tidak stabil. Pengaruh liberal ini kelihatan dalam pendidikan yang mengutamakan prestasi melalui proses persaingan antar murid. Perankingan untuk menentukan murid terbaik, adalah implikasi dari paham pendidikan ini. Pengaruh pendidikan liberal juga dapat dilihat dalam berbagai training management, kewiraswastaan, dan training-training yang lain.

Pendidikan liberal sangat menekankan kompetisi. Padahal kompetisi yangs sehat harus dimulai dengan kondisi yang berimbang, yang tidak sesuai dengan kenyataan bahwa masyarakat (murid khususnya) tidak mempunyai kemampuan yang sama (baik ekonomi, politis, kemampuan personal maupun lainnya) untuk bersaing.

\footnotetext{
14 Amin Nasrulah, Pendidikan Liberal, Reproduksi Kapitalisme, dan Kemandengan Transformasi Sosial, (UIN Yogyakarta: 2003), 82

15 Ibid,...hlm. 81
} 


\section{Abdul Hadi}

Kompetisi tidak berimbang ini akan membawa persoalan yang berkaitan dengan masalah keadilan.

Pendidikan liberal juga membawa suatu misi ideologis tertentu. Dalam pendidikan liberal, misi ideologis yang dibawa tidak lain adalah liberalismekapitalisme itu sendiri. untuk tujuan misi tersebut, pendidikan liberal mengusung wacana-wacana tertentu, yang saat ini telah mendominsi diskursus keilmuan dan pemikiran berbagai kalangan. Wacana dominant dalam pendidikan liberal pada dasarnya dapat diklasifikasikan dalam dua kelompok, pertama bersifat wacana murni dan kedua, bersifat semi ilmiah (

Wacana dalam perkembangan pemikiran yang mendominasi dengan kategori pertama yang sekarang mendominasi berbagai diskursus dan pemikiran berbagai kalangan tidak lain adalah modernisme dengan proyek modernisasinya, globalisme dengan globalisasinya, pasar bebas dan lain sebagainya. Kategori yang kedua, wacana dominant dalam pendidikan liberal, lebih bersifat paradigmatik dan metodologis, misalnya positivisme, objektivisme, fungsionalisme, serta naturalisme, dan netralitas ilmu (ilmu bebas nilai). Positivisme, objektivisme merupakan mainstream dalam pendekatan dan paradigma sains modern. Awalnya pendekatan ini hanya dipakai dalam tradisi ilmu-ilmu pasti (sains), namun belakangan diadopsi dan dipakai sebagai pendekatan dalam ilmu-ilmu sosial dan humaniora. Ironisnya, hegemoni positivisme ini kemudian mendapatkan legitimasi, setelah para ilmuan menetapkannya sebagai atandar ilmiah. Ilmu-ilmu sosial akan dianggap ilmu hanya jika ia memakai dua pendekatan tersebut. ${ }^{16}$

Fenomena tentang pendidikan liberal sangat mendukung dalam memajukan pendidikan yang telah dilakukan dengan berbagai metode maupun pendekatan, semuanya itu untuk perubahan bagi dunia pendidikan saat ini dan menjawab tantangan zaman. Perubahan atau reformasi pendidikan sangat perlu untuk dilakukan, karena akan membuka wawasan baru. Menurut Tilaar ${ }^{17}$ reformasi berarti perubahan dengan melihat keperluan masa depan, menekankan kembali pada bentuk asal, berbuat lebih baik dengan menghentikan penyimpangan-penyimpangan dan praktik yang salah atau memperkenalkan prosedur yang lebih baik, suatu perombakan

\footnotetext{
16 Amin Nasrulah, Pendidikan Liberal, Reproduksi Kapitalisme, dan Kemandengan Transformasi Sosial, Al-Attas Syed Muhammad al-Naquib (terjemahan), Aims and Objectives of Islamic Education. 157

${ }^{17}$ H.A.R. Tilaar, Pendidikan, Kebudayaan, dan Masyarakat Madani Indonesia, (Bandung, PT. Remaja Rosdakarya, 1999), 16
} 
menyeluruh dari suatu sistem kehidupan dalam aspek politik, ekonomi, hukum, sosial, dan tentu saja bisa diterapkan dalam bidang pendidikan. ${ }^{18}$ Liberalisasi pendidikan merupakan salah satu dari reformasi pendidikan, karena liberalisasi memberikan tawaran atau konsep-konsep yang sifatnya memperbaharui dan merubah sistem pendidikan.

Liberalisme pendidikan memiliki tiga corak utama, yaitu:

a. Liberalisme metodis, yaitu bersifat non ideologis dan memusatkan diri pada cara-cara baru dan cara-cara yang telah diperbaiki untuk melancarkan pencapaian sasaran-sasaran pendidikan yang ada sekarang. Penganut kaum liberalisme metodis, mengambil sikap bahwa metode-metode pengajaran (cara-cara belajar-mengajar) harus disesuaikan dengan zaman supaya mencakup renungan-renungan psikologis baru dan hakikat belajar manusia.

b. Liberalisme direktif (liberalisme terstruktur), pada dasarnya kaum liberal direktif menginginkan pembaharuan mendasar dalam tujuan sekaligus dalam hal cara kerja sekolah-sekolah sebagaimana ada sekarang. Mereka menganggap bahwa wajib belajar adalah perlu. Kemudian juga diperlukan kepiawaian memilih beberapa keperluan mendasar tertentu serta mengajukan penetapan lebih dulu tentang isi pelajaran-pelajaran yang akan diberikan pada siswa.

c. Liberalisme non-direktif (libealisasi pasar bebas). Kaum liberalisme nondirektif sepakat dengan pandangan bahwa tujuan dan cara-cara pelaksanaan pendidikan perlu diarahkan kembali secara radikal dari orientasi orotiratian tradisional ke arah sasaran pendidikan yang mengajar siswa untuk memecahkan masalah-masalah sendiri secara efektif.

\section{Implikasi Pendidikan Liberal terhadap pendidikan Islam}

Implikasi pendidikan liberal dapat dilihat dalam keseluruhan proses, sistem dan unsur-unsur serta instrumen pendidikan. Sistem dan proses pendidikan meliputi misalnya, bagaimana proses pembelajaran berlangsung, bagaimana pola interaksi yang dibangun antar guru-murid maupun antar murid, serta bagaimana anggota belajar diperlakukan dan metode pembelajaran yang diterapkan. Dengan asumsi di atas,

18 Dikutip dalam buku, Reformasi Pendidikan; Kritik Kurikulum dan Manajemen Berbasis Sekolah Karangan H.M. Zainuddin, (Yogyakarta: Pustaka Pelajar, 2008), 31 


\section{Abdul Hadi}

bentuk dan mode penindasan dalam pendidikan liberal juga dapat ditemukan melalui analisa terhadap kurikulum pendidikan. ${ }^{19}$

Pendidikan yang telah berjalan di tingkat dasar dan menengah, tentu saja masih banyak kelemahan, tetapi tetap memberikan manfaat, walaupun sedikit, apalagi diketahui selama bertahun-tahun pilihan ideologinya sebetulnya jelas yakni Pancasila, namun substansinya tidak jelas, Pancasila versi yang sedang berkuasa, bukan Pancasila dalam versi sebagaimana para founding fathers inginkan. Oleh karenanya pendidikan selama bertahun-tahun tidak mampu menciptakan manusia-manusia yang bisa menghargai dan menghormati keragaman agama, etnis, kultur dan jenis kelamin bahkan kemampuan intelektual dan emosional.

Pendidikan saat ini cenderung bersifat doktriner (penyuluhan, tidak memberikan alternatif cara pandang siswa/peserta didik, kurang mendorong daya kreatif peserta didik dan menciptakan tumpulnya daya analisis peserta didik) karena lebih ditekankan dimensi kognisinya ketimbang afeksi dan psikomotoriknya. ${ }^{20}$

Sangat jelas implikasi pendidikan liberal bagi dunia pendidikan akan merubah komponen pendidikan, sehingga pendidikan tidak hanya dianggap sebagai perubahan tingkah laku saja tetapi memahami pendidikan sebagai keharusan bagi setiap orang. Saat ini masih ada sebagian orang di Indonesia tidak merdeka untuk menikmati manisnya pendidikan, hal inilah yang harus dirubah demi kemajuan SDM dan berkualitas.

Tradisi liberal telah mendominasi konsep pendidikan hingga saat ini. Pendidikan liberal adalah menjadi bagian dari globalisasi ekonomi liberal kapitalisme. Dalam konteks lokal, paradigma pendidikan liberal telah menjadi bagian dari sistem developmentalisme, dimana sistem tersebut ditegakan pada suatu asumsi bahwa akar 'underdevelopment karena rakyat udak mampu terlibat dalam sistem kapitalisme. Pendidikan harus membantu peserta didik untuk masuk dalam sistem developmentalisme tersebut, sehingga masyarakat memiliki kemampuan dalam kompetisi di system kapitalis yang sekarang mewabah di Negara tercinta ini.

Pada paradigma pendidikan liberal, fokus utama terletak pada bagaimana membuat anak didik memiliki kemampuan sehingga mereka bisa bersaing di tengah sistem yang berlaku pada masyarakat. Pendidikan liberal tidak melihat masalah yang

${ }^{19}$ Amin Nasrulah, Pendidikan Liberal, Reproduksi Kapitalisme ......134

20 Zuly Qodir, Belajar Dari Kisah Kearifan Sababat...6 
berkembang daiam masyarakat karena sistem sosial masyarakat tersebut, tetapi karena ketidaksiapan manusia dalam menghadapi sistem. Sehingga ini akan mengakibatkan pembelajaran yang bersifat memberikan pengetahuan dan keterampilan yang berguna sebanyak-banyaknya kepada anak didik, pengetahuan bersifat doktriner dan menilai sesuatu hanya dengan melihat kecerdasan intelektual yang dimiliki oleh anak didik. Menariknya ideologi pendidikan inilah yang sekarang sedang berkembang ditengahtengah masyarakat global.

\section{KESIMPULAN}

Pendidikan Islam saat ini cenderung mengalami ketepurukan, kenyataannya terdapat beberapa oknum pendidikan yang melakukan kekerasan, korupsi, pendidikan Islam harus mampu mencetak setiap peserta didik yang cerdas, kreatif, dan aktif membaca problem realitas realitas disekitarnya untuk kemudian memberikan alternatif pemecahan. Liberalisasi pendidikan merupakan formula baru untuk merumuskan konsep pendidikan secara ideal sehingga dalam proses belajar-mengajar seorang guru harus memahami perkembangan anak-anak didiknya. Pendidikan Islam dan liberalisasi pendidikan adalah suatu usaha untuk merubah atau mereformasi tatanan pendidikan, sehingga dunia pendidikan lebih maju. Liberalisasi pendidikan bukan berarti sebebas-bebasnya, tetapi harus sejalan dengan nilai-nilai pendidikan Islam yang harus disesuaikan dengan perkembangan zaman sehingga tidak tertinggal untuk mengikuti perkembangan dunia pendidikan.

Model liberalisasi pendidikan Islam pemikiran-pemikiran dalam liberalisasi pendidikan terformulasi dalam berbagai model pendidikan, yaitu; 1) pendidikan Islam yang humanis dasar pemikirannya tidak terlepas dari perspektif ontologism manusia. Manusia secara fitroh merupakan mahluk yang dapat berfikir kritis, bersikap kritis serta mampu membaca dan mengubah realitas dunia. Menempatkan manusia (baik guru/murid) sebagi subjek pendidikan. Jauh sebelum ini ajaran islam telah lebih dahulu menyampaikan hal tersebut. 2) Pendidikan Islam yang membebaskan. Pembebasan dalam pendidikan yaitu upaya-upaya membebaskan manusia dari system pendidikan yang verbal, serba naif, membosankan, dan berbudaya otoriter yang mendikte serta memerintah. Praktik-praktik pendidikan seperti itu dapat mematikan daya kritis dan kreatif manusia itu sendiri. Oleh karena itu, pendidikan seperti itu harus dihapuskan dan diganti dengan konsep pendidikan yang sesuai dengan karakter 


\section{Abdul Hadi}

manusia yang memiliki naluri atau dasar kebebasan. Sementara dalam pendidikan Islam konsep hakiki yang sesuai dengan nilai dalam konsep Islam berorientasi tidak hanya untuk dunia semata melainkan juga sekaligus untuk meraih kesuksesan, kebahagiaan, dan kemaslahatan di alam akhirat.

\section{DAFTAR PUSTAKA}

Adian Husaini, (2005), Islam Liberal, Pluralisme Agama dan Diabolisme Intelektual, Surabaya: Risalah Gusti.

Amin Nasrulah, (2003), Pendidikan Liberal, Reproduksi Kapitalisme, dan Kemandengan Transformasi Sosial, UIN Yogyakarta.

Asnawan, A. (2020). Relevansi Kebijakan dalam Peningkatan Mutu Pendidikan Agama Islam. Tafhim Al-'Ilmi, 11(2), 223-240. https://doi.org/10.37459/tafhim.v11i2.3751

Gerald L Gutek, (1988), Philosophical and Ideological Perspectives on Education, New Jersey: Englewood Cliffs.

Greg Barton, (1999), Gagasan Islam Liberal di Indonesia: Pemikiran Neomodernisme Nurcholish Madjid, Djohan Effendi, Ahmad Wahib, dan Abdurrahman Wahid, Jakarta: Paramadina.

H. M. Zainuddin, (2008), Reformasi Pendidikan; Kritik Kurikulum dan Manajemen Berbasis Sekolah, Yogyakarta: Pustaka Pelajar.

H.A.R. Tilaar, (1999), Pendidikan, Kebudayaan, dan Masyarakat Madani Indonesia, Bandung, PT. Remaja Rosdakarya.

Jasa Ungguh Muliawan, (2005), Pendidikan Islam Integratif: Upaya Mengintegrasikan Kembali Dikotomi Ilmu dan Pendidikan Islam, Yogyakarta: Pustaka Pelajar.

Marjuni, Kapitalisme Dan Pendidikan Liberal, Jurnal wawasan Keislaman, Vol.6 No.2, 2011.

Mansur Isna, (2001), Diskursus Pendidikan Islam, Yogyakarta: Global Pustaka Utama.

Muhammad Chirzin, dkk (2007), Belajar Dari Kisah Kearifan Sahabat: Ikbtiar Pengembangan Pendidikan Islam, Yogyakarta: Pilar Media

Soleh Subagja. (2010) Gagasan Liberalisme Pendidikan Islam. Malang : Madani. 